\title{
Corwin on the Constitution
}

VOLUME ONE

The Foundations of American Constitutional and Political Thought, the Powers of Congress, and the President's Power of Removal

Edited with an Introduction and an Epilogue by RICHARD LOSS

(1) Cornell University Press, Ithaca and London 
Copyright (C) 1981 by Corneil University Press

All rights reserved. Except for brief quotations in a review, this book, or parts thereof, must not be reproduced in any form without permission in writing from the publisher. For information address Cornell University Press, 124 Roberts Place, Ithaca, New York 14850.

First published 1981 by Cornell University Press.

Published in the United Kingdom by Cornell University Press Ltd., Ely House, 37 Dover Street, London W1X 4HQ.

International Standard Book Number 0-8014-1381-8

Library of Congress Catalog Card Number 80-69823

Printed in the United States of America

Librarians: Library of Congress cataloging information appears

on the last page of the book. 

For Ceil Noone, Charles Diehl Brennan, Casimir Bartnik, and Thomas Jaconetty 
Digitized by the Internet Archive in 2018 with funding from Kahle/Austin Foundation 

The question is whether and what history has learned from the experiences that it went through during the Third Reich. To me, it seems, there lies a certain parallel between historical scholarship and jurisprudence: as the latter, through the experience with the unjust state, has turned back from legal positivism to the norms of natural law, so will history have to orient itself not toward legitimizing what exists, but toward drawing normative distinctions, ultimately those of justice and injustice, of good and evildistinctions, as Ranke has said in words that set a limit to all historicism, which are inscribed in the breast of men. The scholarly and the humane conscience go here together, or should do so.-HANs RoTHFELS

In the constitutional mode we can retain our concern for nature and reason and justice and order in our social cosmos without binding ourselves to an impossible quest for final and definitive solutions. Truth about political life then ceases to be a goal that the human mind can attain once and for all. It becomes that measure of prudence and judgment and wisdom that men deploy in the ever-changing process of seeking to maintain living and effective contact between the realm of justice and reason and nature and order on the one hand and the sphere of men's daily doing in an actual political society on the other, a continual rethinking of our belief about the one and a continual reforming of our doings in the other.-J. H. HEXTER 
